\title{
Risk factors and incidence of contrast induced nephropathy following coronary intervention
}

\author{
Yoga Yuniadi, Nurul R Ningrum
}

\begin{abstract}
Abstrak
Contrast induced nephropathy (CIN) merupakan salah satu komplikasi pemberian media kontras yang paling penting. Akan tetapi, insidens dan faktor-faktor yang mempengaruhi CIN setelah suatu tindakan intervensi koroner belum pernah dilaporkan di Indonesia. CIN didefinisikan sebagai peningkatan kreatinin serum sebesar 0,5 mg/dl atau lebih pada hari ke 3 pasca tindakan. Dari 312 subyekyang ikut dalam penelitian ini didapatkan insidens CIN sebesar 25\%. Pada analisis bivariat didapatkan faktor hipertensi, diabetes mellitus, kelas NYHA, volume dan jenis zat kontras, kadar kreatinin serum >1,5 mg/dl, proteinuria dan fraksi ejeksi $\leq 35 \%$ secara bermakna mempengaruhi kejadian CIN. Pada analisis multivariate hanya hipertensi [hazard rasio $(H R)=2,89 ; 95 \%$ interval kepercayaan $(C I)=$ $1,78 \mathrm{~s} / \mathrm{d} 4,71 ; P=0,000]$, diabetes mellitus $(H R=3,09 ; 95 \% \mathrm{CI}=1,89 \mathrm{~s} / \mathrm{d} 5,06, P=0,000)$, fraksi ejeksi $(E F) \leq 35 \%(H R=2,92 ; 95 \%$ $C I=1,72 \mathrm{~s} / \mathrm{d} 4,96 ; P=0,000)$, volume zat kontrast $>300 \mathrm{ml}(\mathrm{HR}=7.73 ; 95 \% \mathrm{CI} 3,09 \mathrm{~s} / \mathrm{d} 19,37 ; \mathrm{P}=0,000)$ dan proteinuria $(H R=$ 14,96; $95 \% C I=3,45 \mathrm{~s} / \mathrm{d}$ 64,86; $\mathrm{P}=0$ 0,000) yang merupakan faktos risiko bebas CIN. Kesimpulannya adalah insidens CIN pada hari ke 3 pada pasien yang dilakukan intervensi koroner sebesar 25\%. Hipertensi, diabetes melitus, EF $\leq 35 \%$, volume zat kontras $>300 \mathrm{ml}$ dan proteinuria merupakan faktor risiko bebas CIN. (Med J Indones 2008; 17: 131-7)
\end{abstract}

\begin{abstract}
Contrast induced nephropathy (CIN) is one of important complication of contrast media administration. Its incidence and risk factors among Indonesian patients undergoing coronary intervention has not been reported yet. CIN was defined as increasing of serum creatinine by $0.5 \mathrm{mg} / \mathrm{dl}$ or more in the third day following contrast media exposure. Of 312 patients undergoing coronary intervention, 25\% developed CIN. Patient-related risk factors comprised of hypertension, diabetes mellitus, NYHA class, proteinuria, serum creatinine $>1.5 \mathrm{mg} / \mathrm{dl}$ and ejection fraction $\leq 35 \%$. Contrast-related risk factors comprised of contrast media volume $>300 \mathrm{ml}$, contrast media type. However, our final model demonstrated that only hypertension [Hazard ratio $(H R)=2.89,95 \%$ confidence intrval $(C I)=1.78$ to 4.71, $P=0.000]$, diabetes mellitus $(H R=3.09,95 \% C I=1.89$ to $5.06, P=0.000)$, ejection fraction $(E F) \leq 35 \%(H R=2.92 ; 95 \% C I=$ 1.72 to 4.96; $P=0.000)$, total contrast volume $>300 \mathrm{ml}(\mathrm{HR}=7.73 ; 95 \% \mathrm{CI}=3.09$ to $19.37 ; \mathrm{P}=0.000)$ and proteinuria $($ HR $=14.96$; $95 \%$ CI $=3.45$ to 64.86; $P=0.000)$ were independent risk factors of CIN. In conclusion, CIN developed in $25 \%$ of patients undergoing coronary intervention. The independent risk factors of CIN included hypertension, diabetes mellitus, EF $\leq 35 \%$, contrast volume $>300$ $\mathrm{ml}$ and proteinuria. (Med J Indones 2008; 17: 131-7)
\end{abstract}

Keywords: contrast induced nephropathy, coronary intervention

Contrast-Induced-Nephropathy (CIN) is one of the important complications of contrast media administration. Nash et $\mathrm{al}^{1}$ reported that CIN was the third most common cause of acute renal failure in hospitalized patients. However, reported incidence of CIN varies among studies, due to differences in definition, background risks, type and dose of contrast medium, imaging procedure, and the frequency of other potential causes of acute renal failure. Currently, incidence of CIN in Indonesia has not been determined.

Department of Cardiology and Vascular Medicine, Faculty of Medicine, University of Indonesia, and National Cardiovascular Center Harapan Kita, Jakarta, Indonesia
Some factors have been identified to increase the risk of CIN, such as diabetes mellitus, age of over 75 years, peri-procedural volume depletion, heart failure, nephrosis, hypertension, proteinuria, NSAID and intra-arterial injection..$^{2-4}$ However, it is uncertain to what extent these factors influence renal function independently. ${ }^{5}$

In the field of cardiology, contrast media has been extensively used during coronary intervention. The National Cardiovascular Center Harapan Kita (NCCHK) as a top cardiology referral and teaching hospital in Indonesia has been leading in interventional cardiology. We hypothesized that the risk of CIN potentially 
increases in NCCHK due to higher dose of contrast media administration by residence. Therefore, this study aimed to elaborate the incidence and factors related to CIN in NCCHK.

\section{METHODS}

\section{Patients}

All patient who underwent coronary intervention using low osmolar monomer contrast media and age of 18 years or older were included in this study. During period of March to May 2006, 312 subjects undergoing coronary intervention were enrolled in this study. Subjects comprised of 156 patients with identified CIN risk factors, and 156 patients without CIN risk factors. Patients received hydration or $\mathrm{N}$-acetyl carbocystein therapy prior to coronary intervention was excluded.

\section{Laboratory Examination}

All patients underwent standard laboratory examination of hemoglobine $(\mathrm{Hb})$, hematocrit $(\mathrm{Ht})$, fasting and post-prandial blood sugar, creatinine and routine urine analysis once during period of 1 week prior to coronary intervention. Three days following coronary intervention creatinine serum was re-measured.

\section{Operational definitions}

CIN is defined as an increase of absolute creatinine serum concentration of $\geq 0.5 \mathrm{mg} / \mathrm{dl}$ at day 3 following coronary intervention. Patient-related risk factors of CIN comprise of hypertension, diabetes mellitus (DM), older age, female gender, preexisting renal disease, heart failure (NYHA class III or IV, ejection fraction of $<35 \%$ ), hypovolemia, low hematocrite level and anemia. Procedure- and contrast-related risk factors comprise of high total volume, high osmolality, high ionic content, and high viscocity of contrast media, intra arterial administration, interval of $<2$ days between contrast-using procedures, emergency procedure, using of intraaortic ballon pump and bypass graft intervention. ${ }^{6}$ Anemia is defined as $\mathrm{Hb}$ of less than $10 \mathrm{~g} / \mathrm{dl}$ both in man or woman. Renal dysfunction is defined as serum creatinine of more than $1.5 \mathrm{~g} / \mathrm{dl}$. Proteinuria was identified by routine urinalysis. Volume status is defined as low hydration if urine specific gravity of $>$ $1.025 \mathrm{or} \mathrm{Hb} / \mathrm{Ht}$ ratio of $>3$.

\section{Statistical Analysis}

Correlation between risk factors and CIN was analyzed using Cox regression. Stata 9 was used to analyze the data. A $P$ value of $<0.05$ considered as statistically significant.

\section{RESULTS}

\section{Clinical Characteristics}

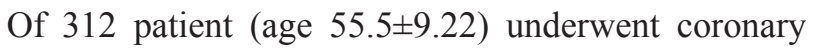
intervention, $78.8 \%$ were male. Diabetes mellitus was found in $16.3 \%$, hypertension in $27.6 \%$, heart failure with NYHA class III in $3.8 \%$, renal dysfunction in $1.6 \%$, and proteinuria in $0.6 \%$ of all subjects. Mean systolic blood pressure was $126.3 \pm 21.07$ and diastolic of $78.8 \pm 12.94 \mathrm{mmHg}$. The average of subjects was normoweight (Body weight of $67.97 \pm 7.73 \mathrm{kgs}$ and height of $165.64 \pm 5.87 \mathrm{~cm}$ ). Patient's volume status at the time of coronary intervention was normal as reflected by urine specific gravity of $1.02 \pm 0.01$. Iopromide contrast media has been mostly used in this population as it cost cheaper than the others. The majority of subjects underwent diagnostic coronary angiography $(59.3 \%)$. Contrast volume administration during coronary angiography (CAG), elective percutaneous trans-coronary angioplasty (PTCA), and CAG plus PTCA was $70.5 \pm 32.94,183.4 \pm 77.13$, and $184.6 \pm 83.34 \mathrm{ml}$ respectively $(\mathrm{p}=0.000)$.

CIN has been observed in 79 patients $(25 \%)$ at day three after coronary intervention, comprised of 51 (33\%) of patients with risk factors and $28(18 \%)$ of patients without risk factors. No significant different of CIN incidence between male (24.4\%) and female (25.8\%). Risk of CIN tends to be higher in older patients (Tabel 1). CIN group also demonstrate higher systolic blood pressure, used much more contrast media, have a lower $\mathrm{Hb}$ and lower ejection fraction as compare to that without CIN. Both fasting and post-prandial blood sugar were significantly higher in CIN group. However, mean value of fasting and post prandial blood sugar within normal limits.

\section{Risk Factors of CIN}

This study revealed that hypertension, DM, proteinuria, renal dysfunction, NYHA class, serum creatinine level of more than $1.5 \mathrm{mg} / \mathrm{dl}$, and ejection fraction $(\mathrm{EF})$ of $\leq 35 \%$ significantly correlated to the CIN occurrence (Table 1). The higher the NYHA class, the higher the risk of CIN. With symptomatic heart failure or NYHA class 3 , the risk of $\mathrm{CIN}$ was 4.55 folds $(\mathrm{P}=0.000)$. Total volume of contrast media only has an effect to 
CIN incidence if administered more than $300 \mathrm{ml}$ (HR of 4.32). Our final mdel revealed that hypertension, DM, $\mathrm{EF} \leq 35 \%$, total contras media volume of more than $300 \mathrm{ml}$, and proteinuria were independent risk factors of CIN (Table 3). Proteinuria markedly increased risk of CIN by almost 15 folds. but the confidence interval was wide.

Table 1. Patient related risk factors

\begin{tabular}{|c|c|c|c|c|c|c|c|}
\hline & \multicolumn{4}{|c|}{$\mathrm{CIN}$} & \multirow{3}{*}{$\begin{array}{c}\text { Hazard } \\
\text { Ratio }\end{array}$} & \multirow{3}{*}{$95 \% \mathrm{CI}$} & \multirow{3}{*}{$\mathrm{P}$} \\
\hline & \multicolumn{2}{|c|}{$\begin{array}{c}\text { No } \\
(\mathrm{n}=235)\end{array}$} & \multicolumn{2}{|c|}{$\begin{array}{c}\text { Yes } \\
(\mathrm{n}=77)\end{array}$} & & & \\
\hline & $\mathrm{n}$ & $\%$ & $\mathrm{n}$ & $\%$ & & & \\
\hline \multicolumn{8}{|l|}{ Age (years) } \\
\hline$\leq 40$ & 8 & 80 & 2 & 20 & 1.00 & Reference & \\
\hline $41-60$ & 166 & 80.2 & 41 & 19.8 & 0.99 & $0.24-4.09$ & 0.989 \\
\hline$>60$ & 61 & 64.2 & 34 & 35.8 & 1.79 & $0.43-7.45$ & 0.424 \\
\hline \multicolumn{8}{|l|}{ Gender } \\
\hline Female & 49 & 74.2 & 17 & 25.8 & 1.00 & Reference & \\
\hline Male & 186 & 75.6 & 60 & 24.4 & 0.97 & $0.55-1.62$ & 0.843 \\
\hline \multicolumn{8}{|c|}{ NYHA class } \\
\hline Class 1 & 223 & 81.7 & 50 & 18.3 & 1.00 & Reference & \\
\hline Class 2 & 10 & 37 & 17 & 63 & 3.44 & $1.98-5.96$ & 0.000 \\
\hline Class 3 & 2 & 16.7 & 10 & 83.3 & 4.55 & $2.31-8.97$ & 0.000 \\
\hline \multicolumn{8}{|c|}{ Hypertension } \\
\hline No & 190 & 84.1 & 36 & 15.9 & 1.00 & Reference & \\
\hline Yes & 45 & 52.3 & 41 & 47.7 & 2.99 & $1.91-4.68$ & 0.000 \\
\hline \multicolumn{8}{|l|}{ DM } \\
\hline No & 222 & 85.1 & 39 & 14.9 & 1.00 & Reference & \\
\hline Yes & 13 & 25.5 & 38 & 74.5 & 4.99 & $3.19-7.79$ & 0.000 \\
\hline \multicolumn{8}{|l|}{ Proteinuria } \\
\hline No & 235 & 75.8 & 75 & 24.2 & 1.00 & Reference & \\
\hline Yes & 0 & 0 & 2 & 100 & 4.13 & $1.02-16.83$ & 0.048 \\
\hline \multicolumn{8}{|c|}{ Creatinine $>1.5 \mathrm{mg} / \mathrm{dl}$} \\
\hline No & 228 & 77.8 & 65 & 22.2 & 1.00 & Reference & \\
\hline Yes & 7 & 36.8 & 12 & 63.2 & 2.85 & $1.54-5.27$ & 0.001 \\
\hline \multicolumn{8}{|c|}{$\mathrm{Hb} \leq 10 \mathrm{~g} / \mathrm{dl}$} \\
\hline No & 231 & 75.7 & 74 & 24.3 & 1.00 & Reference & \\
\hline Yes & 4 & 57.1 & 3 & 42.9 & 1.77 & $0.56-5.60$ & 0.334 \\
\hline \multicolumn{8}{|l|}{$\mathrm{EF} \leq 35 \%$} \\
\hline No & 227 & 81.4 & 52 & 18.6 & 1.00 & Reference & \\
\hline Yes & 8 & 24.2 & 25 & 75.8 & 4.07 & $2.52-6.55$ & 0.000 \\
\hline \multicolumn{8}{|l|}{ ACS } \\
\hline No & 209 & 76.0 & 66 & 24.0 & 1.00 & Reference & \\
\hline Yes & 26 & 70.3 & 11 & 29.2 & 1.22 & $0.65-2.35$ & 0.511 \\
\hline \multicolumn{8}{|c|}{ Antihypertensive agent } \\
\hline Irregular & 201 & 76.1 & 63 & 23.9 & 1.00 & Reference & \\
\hline Regular & 34 & 70.8 & 14 & 29.2 & 1.22 & $0.68-2.18$ & 0.496 \\
\hline
\end{tabular}

$\mathrm{CM}=$ contrast media, NYHA = New York Heart Association, $\mathrm{CAG}=$ coronary angiography, PTCA $=$ percutaneous transcatheter coronary angioplasty, $\mathrm{CI}=$ confidence interval, $\mathrm{ml}=$ mili liter 
Table 2. Contrast- and procedure-related risk factors

\begin{tabular}{|c|c|c|c|c|c|c|c|}
\hline & \multicolumn{4}{|c|}{ CIN } & \multirow{3}{*}{$\begin{array}{c}\text { Crude } \\
\text { Hazard } \\
\text { Ratio }\end{array}$} & \multirow{3}{*}{$95 \%$ Confidence Interval } & \multirow[b]{3}{*}{$\mathrm{P}$} \\
\hline & \multicolumn{2}{|c|}{ No $(n=235)$} & \multicolumn{2}{|c|}{ Yes $(n=77)$} & & & \\
\hline & $\mathrm{n}$ & $\%$ & $\mathrm{n}$ & $\%$ & & & \\
\hline \multicolumn{8}{|l|}{ CM Interval } \\
\hline$>10$ days & 225 & 75.3 & 74 & 24.7 & 1.00 & Reference & \\
\hline$<10$ days & 10 & 76.9 & 3 & 23.1 & 1.07 & $0.34-3.40$ & 0.905 \\
\hline \multicolumn{8}{|l|}{ Contrast Media type } \\
\hline Iopramide (Ultravist) & 153 & 80.5 & 37 & 19.5 & 1.00 & Reference & \\
\hline Iopamidol (Iopamiro) & 55 & 71.4 & 22 & 28.6 & 1.47 & $0.86-2.49$ & 0.154 \\
\hline Iohexol (Omnipaque) & 27 & 60 & 18 & 40 & 2.05 & $1.17-3.61$ & 0.012 \\
\hline \multicolumn{8}{|c|}{ Contrast Media Volume (ml) } \\
\hline$\leq 60$ & 93 & 80.2 & 23 & 19.8 & 1.00 & Reference & \\
\hline $61-120$ & 64 & 74.4 & 22 & 25.6 & 1.29 & $0.72-2.31$ & 0.393 \\
\hline $121-300$ & 77 & 74.8 & 26 & 25.2 & 1.27 & $0.73-2.23$ & 0.399 \\
\hline$>300$ & 1 & 14.3 & 6 & 85.7 & 4.32 & $1.76-10.62$ & 0.001 \\
\hline \multicolumn{8}{|l|}{ Intervention types } \\
\hline CAG & 140 & 76.5 & 43 & 23.5 & 1.00 & Reference & \\
\hline Elective PTCA & 47 & 66.2 & 24 & 33.8 & 1.43 & $0.87-2.37$ & 0.154 \\
\hline CAG + PTCA & 48 & 82.8 & 10 & 17.2 & 0.73 & $0.37-1.46$ & 0.378 \\
\hline
\end{tabular}

$\mathrm{DM}=$ diabetes mellitus, $\mathrm{Hb}=$ hemoglobine, $\mathrm{EF}=$ ejection fraction, $\mathrm{ACS}=$ acute coronary syndrome, $\mathrm{CM}=$ contrast media

Table 3. Relationship between risk factors with CIN

\begin{tabular}{lccc}
\hline $\begin{array}{c}\text { Adjusted } \\
\text { Hazard } \\
\text { Ratio* }\end{array}$ & $\begin{array}{c}95 \% \\
\text { Confidence } \\
\text { Interval }\end{array}$ & P & $\begin{array}{c}\text { Adjusted } \\
\text { Hazard } \\
\text { Ratio* }\end{array}$ \\
\hline Hypertension & 2.89 & $1.78-4.71$ & 0.000 \\
Diabetes mellitus & 3.09 & $1.89-5.06$ & 0.000 \\
Proteinuria & 14.96 & $3.45-64.86$ & 0.000 \\
$\mathrm{CM}$ volume $>300 \mathrm{ml}$ & 7.73 & $3.09-19.37$ & 0.000 \\
$\mathrm{CM}$ type: Iopamidol $\dagger$ & 1.42 & $0.86-2.34$ & 0.177 \\
EF $\leq 35 \%$ & 2.92 & $1.72-4.96$ & 0.000 \\
Creatinin $>1.5 \mathrm{gr} / \mathrm{dl}$ & 1.78 & $0.92-3.45$ & 0.087 \\
\hline
\end{tabular}

*Adjusted each other among risk factors listed in this table; $\uparrow$ Reference group was iopramide; NYHA = New York Heart Association; $\mathrm{EF}=$ ejection fraction; $\mathrm{CM}=$ contrast media

\section{DISCUSSION}

\section{Main Finding}

Overall incidence of CIN in patient undergoing coronary intervention at National Cardiovascular Center Harapan Kita was $25 \%$ at day three. Hypertension, DM, EF $\leq 35 \%$, total contrast volume more than $300 \mathrm{ml}$ and proteinuria are independent risk factors of CIN.

\section{Incidence of CIN}

Incidence of CIN after coronary intervention was variably among studies. McCullough et al reported $14.5 \%$ CIN occur in their series of coronary angio- graphy cases. ${ }^{2}$ Others study reported incidence of $10 \%$ to $15 \% .{ }^{6,7}$ Those discrepancy might be happened due to differences in definition, background risk, type and dose of contrast medium, imaging procedure, and the frequency of other potential causes of acute renal failure. $^{5}$

We defined CIN using a fixed criteria of $0.5 \mathrm{mg} / \mathrm{dl}$ serum creatinine increase, instead of proportionate criteria of $25 \%$ rise in serum creatinine after exposure to contrast media. The selecting parameter was highly sensitive but less specific, as serum creatinine influenced by age, sex and muscle mass. Creatinine clearance is more reliable parameter to determine CIN. ${ }^{8}$ However, since serum creatinine is easier parameter; most studies of CIN have been using it instead of creatinine clearance.

High incidence of CIN in our study population is based on third day serum creatinine level which will not necessarily be persistent during the course of time. Several studies reported that the increasing serum creatinine level will normalized at 10 to 14 days following exposure to contrast media without any sign of renal function compromising. ${ }^{8,9}$ Thus, higher incidence of CIN found in this study might be overestimated. Procedural-related factors might also contribute to the higher incidence of CIN in this study.

Patients who developed CIN used significantly higher volume of contrast media compare to that without CIN $(137.34 \pm 97.55$ vs.109.91 \pm 71.61 respectively, $\mathrm{p}=$ 
$0.025)$. However, there were only 7 (2.2\%) patients received more than $300 \mathrm{ml}$ contrast media and 6 $(85.7 \%)$ of them developed CIN. In contrast, only $25.4 \%$ patients who received $\leq 300 \mathrm{ml}$ contrast media developed CIN $(\mathrm{p}=0.001)$. Previous study showed that every $100 \mathrm{ml}$ of contrast administration increase the CIN risk score by $1 .{ }^{4}$ The hypothesis of excess contrast media administration in teaching hospital by the residence was not proven as contrast media administered during any types of coronary intervention in our study was comparable to the previous study. ${ }^{10,11}$

\section{Independent risk factors}

CIN is mediated predominantly by outer medullary hypoxic tubular damage, probably combined with and accentuated by endothelial dysfunction and renal microcirculatory alterations. ${ }^{12,13}$ Altered protective mechanisms also bring about the susceptibility to develop CIN in high-risk patients. Indeed, predisposing risk factors, such as preexisting renal dysfunction, diabetes, and congestive heart failure, are all characterized by compromised medullary oxygen sufficiency, related to defective nitric-oxide-dependent renal vasodilatation or prostaglandin synthesis, by increased reabsorptive work load, by enhanced systemic vasoconstrictive stimuli, or by structural changes of the renal microcirculation..$^{13}$ Tubular obstruction, direct toxic effects of the dye because of apoptosis, and oxidative damage may also play a role. ${ }^{14}$

Several risk factors of CIN have been observed from many studies. They comprised of patient factors such as DM, hypertension, older age, dehydration, sex, heart failure and renal dysfunction; and contrast media factor such as osmolarity, volume and type of contrast media. Our study showed that patients who developed CIN had older age; longer duration of hypertension, DM, and renal dysfunction; higher fasting and post-prandial blood sugar; and lower ejection fraction.

Our final model revealed that the CIN independent risk factors in our study comprised of hypertension, DM, proteinuria, total contrast media volume of more than $300 \mathrm{ml}$, and ejection fraction of $\leq 35 \%$. Mehran et al. ${ }^{4}$ developed a simple scoring method that integrates eight baseline clinical variables to assess the risk of CIN following percutaneous coronary intervention (PCI). These are hypotension (score 5), the use of an intraaortic balloon pump (score 5), congestive heart failure (score 5), a serum creatinine level $>1.5 \mathrm{mg} / \mathrm{dl}$ (score 4 ), age $>75$ years (score 4 ), anemia (score 3 ), diabetes mellitus (score 3), and the volume of contrast media (score $1 / 100 \mathrm{ml}$ ). If the total score is 5 or less, the risk category is low; if the total score is 16 or higher, the risk category is very high.

In our study, patient with risk factors developed almost doubled of CIN as compare to that without risk factors. NYHA class predicts the incidence of CIN, in which better NYHA class associated with less occurrence of CIN. NYHA classification of functional status was developed to grade the severity of chronic heart failure. NYHA class is associated linearly with ejection fraction. We found that ejection fraction of $\leq 35 \%$ increase risk of CIN by 2.92 folds $(p=0.000)$. Previous studies have shown that a reduced left ventricular ejection fraction $(\leq 49 \%)$ and advanced congestive heart failure (NYHA class III or IV) are independent risk factors for CIN..$^{15,16}$ Dangas et al. ${ }^{17}$ showed that a left ventricular ejection fraction of $<40 \%$ is an independent predictor of CIN. Toprak et al. ${ }^{18}$ has previously reported that if the left ventricular ejection fraction is $>30 \%$, this condition does not show any significant effect on the development of CIN. Advanced heart failure and reduced left ventricular ejection fraction are characterized by effective volume depletion caused by low cardiac output and increased neurohumoral vasoconstrictive stimuli and impaired nitric-oxide-dependent renal vasodilation that might compromise the medullary oxygenation. ${ }^{12,13}$ In the study done by Rihal et al. ${ }^{3}$, it was shown that congestive heart failure is an independent risk for $\mathrm{CIN}(\mathrm{OR}=1.53, \mathrm{p}=$ 0.007). In a cohort study, Bartholomew et al. ${ }^{19}$ found that congestive heart failure is a risk for $\mathrm{CIN}$ in patients who underwent PCI $(\mathrm{OR}=2.2, \mathrm{p}<0.0001)$.

Contrast media may influence the incidence of CIN with regard to type, volume and time interval to the previous contrast exposure. The total volume of contrast has been proved to be independent risk factors of CIN in our study. With cut of point of $300 \mathrm{ml}$, total volume of contrast media increased risk of CIN by 7.73 folds $(p=$ 0.000 ). The correlation of volume of contrast medium administered with the risk of nephropathy has been described previously. ${ }^{2,3,20}$ In a series of consecutive patients undergoing coronary angiography, each $100 \mathrm{ml}$ of contrast medium administered was associated with a significant increase of $12 \%$ in the risk of nephropathy. ${ }^{3}$ Adjustment of the volume to the patient's body weight and serum creatinine level has been found to minimize the risk.

Similarly, it has been shown that exceeding a patientspecific maximum volume of contrast medium (recommended to be $5 \mathrm{ml} \times$ [body weight (kilograms)/ serum creatinine level (micromoles per liter) $\div$ 
88.4]) is associated with a 12 -fold increase in risk of hemodialysis. ${ }^{20}$ Therefore, the amount of contrast medium used should be kept to a minimum and not exceed patient-specific maximum doses. Other than volume, type of contrast media correlates to CIN as well. Almen et al. is the first to introduce non-ionic monomer low osmolar contrast which then followed by the development of dimer type. With 6 iodine atoms in each molecule of dimer type result in a low osmolarity contrast media which is approaching blood osmolarity. Even though all contrast media used in this study were low osmolar non-ionic monomer type but the incidence of CIN differed between them. With reference of iopramide (Ultravist ${ }^{\mathbb{R}}$ ) as most used contrast media, iohexol (Omnipaque ${ }^{\circledR}$ ) utilization had the highest risk of CIN [hazard ratio (HR) of 2.05, 95\% confidence interval $(\mathrm{CI})=1.17$ to 3.61 ) followed with iopamidol (Iopamiro $^{\circledR}$ ) (HR $1.47,95 \%$ CI 0.86 to 2.49 ). Similar results have been reported previously. The data taken from various randomized, double-blind comparisons of contrast agents showed that iohexol caused a higher CIN incidence as compare to that of iopamidol, iomeprol and iopromide. All patients in these studies were reported to have been adequately hydrated and all studies involved intra-arterial administration of the contrast material. CIN occurred with a frequency of 21$26 \%$ in studies with iohexol, $6-12 \%$ with iopamidol, $16 \%$ with iomeprol and $11 \%$ with iopromide. However, it is not clear that an accurate comparison can be made, since the relevant variables, including calculated creatinine clearance, route of contrast administration, dose of contrast administration, presence or absence of diabetes mellitus, nature of pre-hydration and presence or absence of other risk factors, are neither uniform nor necessarily clear in the various studies. ${ }^{8}$ In addition, multivariate analysis did not show any significant of contrast media type in occurrence of CIN.

Hypertensive patients had 2.89 fold risk of CIN following coronary intervention as compare to normotensive patients. Hypertension has been categorized as a risk factor for CIN in some studies. Goldenberg et al ${ }^{12}$ showed similar results, but odds ratio was 1.2. In our study, hypertension found in $27.6 \%$ of total subjects and among them $47.7 \%$ developed CIN. In contrast, only $15.9 \%$ of normotensive patient developed CIN. In addition, only $16 \%$ of hypertensive patients underwent regular checked and took antihypertensive. The alterations of intrarenal expression of vasoactive mediators, such as renin-angiotensin system or nitric oxide in hypertensive patients may contribute to the
CIN occurrence. A reduced number of nephrons could also predispose hypertensive patients to CIN. ${ }^{6}$ Furthermore, a study of 8,628 patients who underwent PCI, ${ }^{19,21}$ revealed that hypertension was an independent predictor of CIN (OR of 1.2 to 2.0). Systolic instead of diastolic blood pressure demonstrated significant correlation to the CIN incidence. It can be explained with that systolic blood pressure in CIN patients was significantly higher and the possibility higher incidence of isolated systolic hypertension in our study population which was having mean age of $55.5 \pm 9.22$ years.

The mechanisms of CIN in DM patients are compromise of nitric oxide mediated renal vasodilation and significant decrease of oxygen partial pressure at outer renal medulla due to endothelial dysfunction. Diabetic subjects had blood sugar concentration of $144.4 \pm 35.42$ $\mathrm{g} / \mathrm{dl}$ and $225.5 \pm 65.22 \mathrm{~g} / \mathrm{dl}$ during fasting and 2 hours post-prandial respectively. With that poor glycaemic control it seems logic that patients with DM had 3.09 folds $(\mathrm{p}=0.000)$ risk of CIN following coronary intervention.

In addition, serum creatinine concentration of DM patients was higher as compare to that non-DM (1.25 \pm 0.42 vs. $1.02 \pm 0.28$ respectively, $p=0.000$ ), which may further increase CIN probability. Furthermore, the overall fasting and post-prandial blood sugar significantly correlated to CIN. In CIN group, the fasting and post-prandial blood sugar (116.05 \pm 9.17 and $170.59 \pm 20.90 \mathrm{mg} / \mathrm{dl}$ respectively) were higher than normal. Since the diabetic patients were $49.4 \%$ of all CIN group, it demonstrated that diabetic patients who developed CIN had very poor glycaemic control.

Proteinuria or microalbuminuria is a marker of endothelial dysfunction and frequently associated with diabetes and hypertension. In our study, non-diabetic and non-hypertensive proteinuria independently increased risk of CIN by 14.96 folds $(\mathrm{P}=0.000)$. Actually only 2 patients in our study suffered from non-diabetic and nonhypertensive proteinuria. Among them, all developed CIN then produced very significant result statistically but may not important clinically. If we look at overall proteinuria patients including those with diabetics and hypertensive, the HR of CIN markedly increases to $9.11(\mathrm{P}=0.005)$. Among overall proteinuria, $52.6 \%$ and $73.7 \%$ were diabetics and hypertensive respectively.

Analysis of combine risk factors of diabetes and proteinuria increase CIN by 3.99 folds $(95 \% \mathrm{CI} 1.99$ to $8.01, \mathrm{P}=0.000)$ and combination of hypertension and proteinuria had HR of $3.93(95 \%$ CI 2.12 to $7.27, \mathrm{P}=$ 
0.000). This data demonstrated the role of multiple risk factors associated with proteinuria in developing of CIN. Diabetics and hypertensive patients with evident of endothelial dysfunction were more susceptible to contrast media administration.

\section{Study limitations}

Short observation of subjects may overestimate the incidence of CIN since serum creatinine may normalize 5 to 10 days following contrast administration. However, the aim of this study was to seek acute renal dysfunction induced by contrast media which has been reported peaked at third day following contrast exposure. Although serum creatinine is not an ideal parameter of renal dysfunction due to influence of age and gender, but majority of CIN studies have been using it for CIN criteria.

In conclusion, incidence of CIN among patient undergoing coronary intervention in NCCHK is $25 \%$ which is comparable to others studies. Hypertension, $\mathrm{DM}, \mathrm{EF} \leq 35 \%$, total contrast volume $>300 \mathrm{ml}$ and proteinuria are independent risk factors of CIN.

\section{Acknowledgment}

Authors address gratitude and appreciation to Prof. Bastaman Basuki, MD who has been kindly discussed and reviewed on statistic results extensively.

\section{REFERENCES}

1. Nash K, Hafeez A, Hou S. Hospital-acquired renal insufficiency. Am J Kidney Dis. 2002;39:930-6.

2. McCullough PA, Wolyn R, Rocher LL, et al. Acute renal failure after coronary intervention: incidence, risk factors, and relationship to mortality. Am J Med. 1997;103:368-75.

3. Rihal CS, Textor SC, Grill DE, et al. Incidence and prognostic importance of acute renal failure after percutaneous coronary intervention. Circulation. 2002; 105:2259-64.

4. Mehran R, Aymong ED, Nikolsky E, et al. A simple risk score for prediction of contrast-induced nephropathy after percutaneous coronary intervention: development and initial validation. J Am Coll Cardiol. 2004;44:1393-9.

5. Barret JB, Parfrey PS. Preventing nephropathy induced by contrast medium. N Engl J Med. 2006;354:379-86.

6. Toprak O, Cirit M. Risk Factors for Contrast-Induced Nephropathy. Kidney Blood Press Res. 2006;29:84-93.

7. Kramer B, Kammerl M, Schweda F, et al. A primer in radiocontrast-induced nephropathy. Nephrol Dial Transplant. 1999; $14: 2830-4$
8. Bettmann MA. Contrast medium-Induced Nephropathy: critical review of the existing clinical evidence. Nephrol Dial Transplant. 2005; 20 (suppl 1):i12-7.

9. Davidson CJ, Hlatky M, Morris KG, et al. Cardiovascular and renal toxicity of a nonionic radiographic contrast agent after cardiac catheterization: a prospective trial. Ann Intern Med. 1989;110:119-24.

10. Chahoud G, Khoukaz S, El-Shafei A, et al. Randomized comparison of coronary angiography using $4 \mathrm{~F}$ catheters: $4 \mathrm{~F}$ manual versus "Acisted" power injection technique. Cathet Cardiovasc Intervent. 2001;53:221 - 4 .

11. Anne G, Gruberg L, Huber A, et al. Traditional Versus Automated Injection Contrast System in Diagnostic and Percutaneous Coronary Interventional Procedures: Comparison of the Contrast Volume Delivered. J Inv Cardiol. 2004; 16:360-2.

12. Goldenberg I, Matetzky S. Nephropathy induced by contrast media: pathogenesis, risk factors and preventive strategies. CMAJ. 2005;172:1461-71

13. Heyman SN, Rosenberger C, Rosen S. Regional alterations in renal haemodynamics and oxygenation: a role in contrast medium-induced nephropathy. Nephrol Dial Transplant. 2005; 20: Suppl 6-11.

14. Itoh Y, Yano T, Sendo T, et al. Clinical and experimental evidence for prevention of acute renal failure induced by radiographic contrast media. J Pharmacol Sci. 2005; 97: 473-88.

15. Gruberg L, Mintz GS, Mehran R, et al. The prognostic implications of further renal function deterioration within $48 \mathrm{~h}$ of interventional coronary procedures in patients with preexistent chronic renal insufficiency. J Am Coll Cardiol. 2000;36:1542-8.

16. Schillinger M, Haumer M, Mlekusch W, et al. Predicting renal failure after balloon angioplasty in high-risk patients. J Endovasc Ther. 2001;8:609-614.

17. Dangas G, Iakovou I, Nikolsky E, et al. Contrast-induced nephropathy after percutaneous coronary interventions in relation to chronic kidney disease and hemodynamic variables. Am J Cardiol 2005;95:13-9.

18. Toprak O, Cirit M, Bayata $\mathrm{S}$, et al. Is there any relationship between left ventricular ejection fraction and contrast induced nephropathy? Turk Klin J Med Sci. 2003;23:104-7.

19. Bartholomew BA, Harjai KJ, Dukkipati S, et al. Impact of nephropathy after percutaneous coronary intervention and a method for risk stratification. Am J Cardiol. 2004; 93:1515-9.

20. Freeman RV, O’Donnell M, Share D, et al. Blue Cross-Blue Shield of Michigan Cardiovascular Consortium (BMC2). Nephropathy requiring dialysis after percutaneous coronary intervention and the critical role of an adjusted contrast dose. Am J Cardiol. 2002;90:1068-73.

21. Iakovou I, Dangas G, Mehran R, et al. Impact of gender on the incidence and outcome of contrast-induced nephropathy after percutaneous coronary intervention. J Invasive Cardiol. 2003;15:18-22. 